\section{Abortion and sex-related conditions in substance-dependent Brazilian patients}

\author{
Aborto e saúde sexual e reprodutiva entre \\ dependentes químicas brasileiras
}

\section{Aborto y salud sexual y reproductiva entre drogodependientes brasileñas}

\author{
Alessandra Diehl 1 \\ Sandra Cristina Pillon 2 \\ Manoel Antonio dos Santos 3 \\ Ronaldo Laranjeira 1
}

doi: 10.1590/0102-311X00143416

\begin{abstract}
Abortion is a very sensitive issue with relevance to public health; however few clinical or population-based studies have examined induced abortion among drug users. The study aims to evaluate the prevalence of induced abortion and sex-related conditions in an inpatient drug user sample. A cross-sectional design study was conducted in an inpatient addiction treatment unit in São Paulo, Brazil, with a sample of 616 patients, aged 18-75. Sociodemographic data, sexual behavior, and dependence severity were evaluated in relation to induced abortion. Approximately 27\% of patients reported having a history of abortion (themselves in the case of women or partners in the case of men).

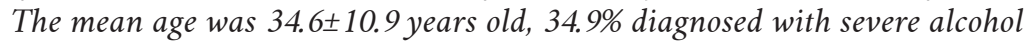
dependence, 33\% were diagnosed with severe levels of dependence on other drugs, 69.6\% were diagnosed cocaine users (inhaled and smoked), and alcohol was the drug of choice for 30.4\%. Chances of having a history of abortion is greater for women than for men with a odds ratio $(O R=2.9 ; 95 \% \mathrm{CI}$ : 1.75-4.76), $(O R=1.7 ; 95 \% C I$ : 1.09-2.75) of no condom use; $(O R=2.0$; 95\%CI: 1.35-3.23) of history of STI and (OR = 3.2; 95\%CI: 1.29-5.73) use of morning-after pill. Drug-and alcohol-dependent patients have high-risk behaviours of sporadic use or no-condom use which contribute to unplanned pregnancy and induced abortion, making this vulnerable population a group which deserves special attention in sexual health prevention programmes and health promotion efforts for the reduction of induced abortion.
\end{abstract}

Abortion; Sexual and Reproductive Health; Drug Users; Substance-related Disorders; Public Policies

\author{
Correspondence \\ A. Diehl \\ Unidade de Pesquisa em Álcool e Drogas, Universidade Federal \\ de São Paulo. \\ Rua Botucatu 394, São Paulo, SP 04038-001, Brazil. \\ alediehl@terra.com.br \\ 1 Unidade de Pesquisa em Álcool e Drogas, Universidade Federal \\ de São Paulo, São Paulo, Brasil. \\ 2 Escola de Enfermagem de Ribeirão Preto, Universidade de São \\ Paulo, Ribeirão Preto, Brasil. \\ 3 Faculdade de Filosofia, Ciências e Letras de Ribeirão Preto, \\ Universidade de São Paulo, São Paulo, Brasil.
}




\section{Introduction}

Abortion is a very sensitive and relevant public health issue which involves social, psychological, ethical, moral and religious concerns 1,2,3. This important taboo subject still generates controversies and disputes in many countries around the world 4,5, including Brazil and other Latin American countries 6 .

Concerns about abortion arise in debates during political and electoral campaigns 7,8 and anti-abortion views are extremely common in countries where population majority is Roman Catholic or another Christian religion 7. Yet, there have been discussions and advances in some Latin American countries, such as Mexico and Uruguay, where abortion was legalized despite the Christian population majority 9,10 .

Brazilian legislation forbids induced abortion, except when the pregnancy is life-threatening to the mother or results from a rape or sexual assault. Even when there is a severe foetal malformation as in anencephaly, abortion is only permitted after judicial authorization 9,11. Still, little progress in this field has been observed from the public health perspective in Brazil, as the complications of abortion are among the major causes of maternal mortality 9,12, which seems to be repeatedly true for the most vulnerable population, such as the chronic drug users 13,14,15,16,17,18.

Being an illegal practice has not prevented abortions from taking place contributing to the use of unsafe techniques, therefore reducing statistic reliability of this type of practice since illegal abortion is even less reported 12. In 2008, there was one abortion for every four pregnancies in Brazil (25\%) 9. Many methods have been used to induce abortion, varying from safe procedures conducted in illegal private health clinics to home-based procedures, exposing women to complication and mortality risk. Due to inequalities within the country death is three times more likely to occur to African descendent women than to white women due to unsafe abortion procedures 9,19. To complete the death vulnerability profile we must add youth and those with low income. In other words, those who are able to pay for illegal abortion are less likely to have complications or die 9,20.

Unplanned pregnancy is a common occurrence among women of reproductive age. Unintended pregnancy is among the major contributors to abortion and many women rely on abortion as a primary birth control method 21. In Brazil, it is estimated that 1.8 million unplanned pregnancies result in 159,151 miscarriages, 48,769 induced abortions, 1.58 million live births and 312 maternal deaths, including 10 (3\%) attributed to unsafe abortions. It is estimated that the cost of an unplanned pregnancy is equivalent to BRL 2,293 in Brazil. The abortion cost to health represents a small proportion of the total cost. However, these are generally paid out by the public health system 22 .

It is believed that drug users are vulnerable to unplanned pregnancy and induced abortion, with propensity to higher rates when compared to the general population 12,23 due to risky sexual behaviors such as low condom use and high number of sexual partners 24 . Substance use during pregnancy is regarded as a serious problem in medical settings and in the criminal justice system 5,11, but very few studies have observed large samples to evaluate induced abortion among drug users and alcoholdependent patients.

A study with 91 female drug users found that $53 \%$ were sexually active in four weeks preceding the research, $66 \%$ acknowledged to have experienced sexual intercourse which could have led to pregnancy during those four weeks, and $55 \%$ had been forced to have sex against their will in their lifetime. Moreover, this sample presented high rates of sexually transmitted infections (STIs), pregnancy termination, and miscarriage indicating the need to recognize the extent of elevated sexual health risks and morbidities experienced by substance users with long-term opioid and crack use 14 .

Crack use has increased over the past decade in many countries around the world 25 and its use has been associated to pregnancy termination 26,27. A study evaluated a sample of 125 women crack users from the underprivileged communities in Salvador, Bahia State, Brazil, of whom 90\% had low education levels and high unemployment, 37\% reported having sex for money or drugs and $58 \%$ reported they had not used condoms during sexual intercourse over the previous 30 days. The study reinforces the concept that women who use crack are a significant vulnerable group in regard to STIs transmission and unplanned pregnancies 28 .

The risks associated to abortion are also higher among female injecting drug users (IDUs) because they are already more likely to have worse health conditions and clinical comorbidities, such as hepatitis C, HIV and other addictive disorders. Female IDUs may be more vulnerable to impoverishment 
and discrimination, fading the ability to provide appropriate health care interventions 29 . A study conducted with 80 sexually active IDU women in Saint Petersburg, Russia, showed that $67 \%$ had undergone abortion and consistent condom use was reported by only $22 \%$ of the subjects 13 .

More evidence on induced abortion in drug users in clinical settings and population-based studies may help programme planners and policy makers to identify groups at greater risk for unintended pregnancy and reduce abortion-related health risks among drug users, and further help guide and evaluate the best prevention efforts and health promotion approaches for this vulnerable population. This study aimed to evaluate the prevalence of induced abortion and sex-related conditions in a sample of inpatient drug users.

\section{Methods}

This study was a cross-sectional design conducted in an inpatient addiction treatment unit in São Paulo, Brazil. The sample comprised 616 consecutive admission of alcohol and cocaine users (smoked and inhaled), aged 18 years old or older with a confirmed clinical dependence diagnosis according to the Diagnostic and Statistical Manual of Mental Disorders IV, text revised (DSM-IV-TR) diagnosis criteria. Data collection was performed from May 2009 to November 2011, all patients admitted in the period above were approached within 14 days from admission date by a trained team constituted by a psychologist, an occupational therapist and a nurse. Interview protocol average duration was 50 minutes. No refusals were recorded 30 .

\section{Measures}

\section{- Sexual behavior}

It was examined by simple question about lifetime history of induced abortion (dependent variable was investigated both in women and the abortion experience lived by the men through sexual partners), condom use frequency in the last 12 months, number of sexual partners in the last 12 months, history of sex with sex workers in the last 12 months, sexual orientation identity, lifetime homosexual experience in exchange for drugs, lifetime history of STIs, age at the time of first intercourse (vaginal, anal, oral).

\section{- Sociodemographic data}

The sociodemographic data included simple question about age, educational level, race, marital status, monthly income, occupational status, and religious affiliation.

Characteristics related to the treatment of the substance-related disorder. It was examined by simple question about the length of substance abuse and the number of previous treatments excluding the present treatment.

\section{- Drug of choice}

Data were collected on the individual preferred drug. This information was elicited directly by the simple question "What is your drug of choice?" Although substance users often meet the diagnostic criteria for dependence on multiple drugs, drug of choice is usually included in the patient clinical status because it assists in the user profile identification for appropriate case management provision 31 .

\section{- Drug Abuse Screening Test (DAST) 20}

The DAST is a scale consisted of 20 questions related to drug use within the last year. The questions pertained specifically to abuse, dependence, withdrawal (signs and symptoms), social impairment, family relations, legal implications, medical problems, and previous treatment history. The severity of the drug problem was classified on a scale from 0 to 20 and was scored as follows: $0=$ no problem; 1 to 
$5=$ mild; 6 to $10=$ moderate; 11 to $15=$ substantial; 16 to $20=$ severe. Reliability and validity measures have been reported to be satisfactory in all the versions for use as a clinical and or research tool 32.

\section{- Short Alcohol Dependence Data (SADD)}

The SADD is a scale consisted of 15 questions related to the alcohol dependence severity, classified on a scale from 0 to 20, and scored as follows: mild (0-9), moderate (10-19) and severe ( $\geq 20)$. The Brazilian version and the original English version of the SADD are highly correlated and the coefficient of internal consistency is 0.7933 .

\section{- Fagerström Test for Nicotine Dependence (FTND)}

The FTND scale is a screening instrument extensively used and translated in many countries, including Brazil, for physical nicotine dependence assessment. The instrument consists of six items that are easily understood and rapidly applied. The scores obtained on the test allow nicotine dependence classification into five levels: very low (0 to 2 points); low ( 3 to 4 points); moderate ( 5 points); high (6 to 7 points); very high ( 8 to 10 points). The reliability index is excellent (0.87) and the Cronbach's alpha coefficient ranges from 0.55 to 0.74 , indicating that the FTND has moderate internal consistency. FTND exhibits satisfactory sensitivity $(0.75)$ and specificity $(0.80) 34$.

\section{Data analysis}

A descriptive data analysis was initially performed. For the categorical variables, absolute and relative frequencies were presented, and for the numerical variables, frequency measurements (mean, minimum, maximum, and standard deviation) were presented. Statistical analyses include the chisquare test or Fisher's exact test for small samples, Student's t-test for independent samples and logistic regression. For all the statistical tests, a significance level of 5\% was considered. A multivariate analysis was conducted through binary logistic regression to obtain estimated odds ratio (OR) 95\% confidence intervals (95\%CI) adjusted to confounding variables. Variables included in this model were associated to induced abortion history with $\mathrm{p}<0.20$ in the bivariate analysis. The variables which remained in the model were only the variables with statically significant values $(\mathrm{p}<0.05)$. The dependent variable was induced abortion history (dichotomic) and independent variables were gender, marital status, educational level, occupational status, SADD, DAST, tobacco, FTND, sexual activity in the past 12 months, condom use, history of STIs, HIV testing and use of the morning-after pill. For all the statistical tests, a significance level of $5 \%$ was considered. The statistical analyses were performed using the IBM SPSS version 20 (IBM Corp., Armonk, USA).

\section{Ethical approval}

This study was approved by the Federal University of São Paulo (UNIFESP) Ethics Committee (protocol number 1193/09) and all the subjects signed an informed consent form.

\section{Results}

\section{Sociodemographic data}

The sample comprised a total of 616 inpatient drug users, 508 (82.5\%) men and 108 (17.5\%) women, predominantly adults (mean $34.6 \pm 10.9$ years old) ranging in age from 18 to 75 years, unmarried (77.6\%), Catholic (52.7\%), Caucasian (54.5\%), non-registered employee/liberal profession and unemployed (67.9\%), with low levels of education (47.2\%) and income (36.1\%) (Table 1). Many of the sociodemographic variables in this study were found to be significantly associated with a history of induced abortion (Table 1). A total of 165 (26.8\%) participants reported a history of induced abortion in their lives. In the sample, 40.7 of the women had a history of abortion. However, there was 
Sociodemographic data and history of induced abortion.

\begin{tabular}{|c|c|c|c|c|c|c|c|}
\hline & \multicolumn{6}{|c|}{ History of induced abortion } & \multirow[t]{4}{*}{ p-value } \\
\hline & \multirow{2}{*}{\multicolumn{2}{|c|}{$\begin{array}{c}\text { Total } \\
(n=616 ; 100.0 \%)\end{array}$}} & \multirow{2}{*}{\multicolumn{2}{|c|}{$\begin{array}{c}\text { Yes } \\
(n=165 ; 26.8 \%)\end{array}$}} & \multirow{2}{*}{\multicolumn{2}{|c|}{$\begin{array}{c}\text { No } \\
(n=451 ; 73.2 \%)\end{array}$}} & \\
\hline & & & & & & & \\
\hline & $\mathbf{n}$ & $\%$ & $\mathbf{n}$ & $\%$ & $\mathbf{n}$ & $\%$ & \\
\hline \multicolumn{8}{|l|}{ Gender } \\
\hline Male & 508 & 82.5 & 121 & 23.8 & 387 & 76.2 & $<0.001$ * \\
\hline Female & 108 & 17.5 & 44 & 40.7 & 64 & 59.3 & \\
\hline \multicolumn{8}{|l|}{ Marital status } \\
\hline Unmarried & 478 & 77.6 & 118 & 24.7 & 360 & 75.3 & 0.020 * \\
\hline Married/Stable union & 138 & 22.4 & 47 & 34.1 & 91 & 65.9 & \\
\hline \multicolumn{8}{|l|}{ Ethnicity/Skin color/Race } \\
\hline White & 336 & 54.5 & 101 & 30.1 & 235 & 69.9 & 0.027 * \\
\hline Non-white & 280 & 45.4 & 64 & 22.9 & 216 & 77.1 & \\
\hline \multicolumn{8}{|l|}{ Religion } \\
\hline Catholic & 325 & 52.7 & 73 & 22.5 & 252 & 77.5 & \\
\hline Evangelical & 130 & 21.2 & 43 & 33.1 & 87 & 66.9 & 0.070 \\
\hline Spiritualist/Umbanda/Candomblé/Other & 81 & 13.2 & 26 & 32.1 & 55 & 67.9 & \\
\hline Atheist/No religion & 80 & 12.9 & 23 & 28.7 & 57 & 71.3 & \\
\hline \multicolumn{8}{|l|}{ Educational level } \\
\hline Illiterate & 72 & 11.7 & 69 & 95.8 & 3 & 4.2 & \\
\hline Elementary school & 219 & 35.5 & 156 & 71.2 & 63 & 28.8 & $<0.001$ \\
\hline Secondary school & 223 & 36.2 & 161 & 72.2 & 62 & 27.8 & \\
\hline Higher education/Graduate education & 102 & 16.5 & 65 & 63.7 & 37 & 36.3 & \\
\hline \multicolumn{8}{|l|}{ Occupational status } \\
\hline Retired & 16 & 2.6 & 7 & 43.8 & 9 & 56.3 & \\
\hline Registered employee & 171 & 27.8 & 45 & 26.3 & 126 & 73.7 & 0.014 \\
\hline $\begin{array}{l}\text { Non-registered employee/Liberal } \\
\text { profession }\end{array}$ & 356 & 57.8 & 95 & 26.7 & 262 & 73.3 & \\
\hline Fully unemployed & 62 & 10.1 & 11 & 17.7 & 51 & 82.3 & \\
\hline Housewife & 11 & 1.8 & 7 & 63.6 & 4 & 36.4 & \\
\hline \multicolumn{8}{|l|}{ Income (minimum wage **) } \\
\hline$\leq 1$ & 225 & 36.1 & 45 & 20.0 & 180 & 80.0 & \\
\hline $2-3$ & 215 & 34.9 & 63 & 29.3 & 152 & 70.7 & 0.022 \\
\hline $4-5$ & 98 & 15.9 & 27 & 27.6 & 71 & 72.4 & \\
\hline $6-7$ & 28 & 4.5 & 11 & 39.3 & 17 & 60.7 & \\
\hline$\geq 7$ & 50 & 8.1 & 19 & 38.0 & 31 & 62.0 & \\
\hline
\end{tabular}

* Descriptive level of Fisher's exact test ( $p$-value $\leq 0.005) \mathrm{N}=616$.

** Minimum wage: BRL 724 or USD 280.18.

Note: descriptive level of the chi-squared test (test statistics; degrees of freedom) $\mathrm{N}=616$.

induced abortion history predominance among female participants $\left(40.7 \%, \chi^{2}(1)=13.005, \mathrm{p} \leq 0.001\right)$, married/stable union $\left(34.1 \%, \chi^{2}(1)=4.796, p=0.020\right)$, Caucasian $\left(30.1 \%, \chi^{2}(1)=4.040, p=0.044\right)$, illiterate $\left(95.8 \%, \chi^{2}(3)=24.023, \mathrm{p} \leq 0.001\right)$, housewife $\left(63.6 \%, \chi^{2}(3) \mathrm{p} \leq 0.014\right)$, income (6-7 minimum wage $[\mathrm{MW}] ; 1 \mathrm{MW}=\mathrm{BRL} 724$ or USD 280$)\left(39.3 \%, \chi^{2}(4)=11.444, \mathrm{p}=0.022\right)$, with statistically significant associations.

When comparing mean age, no statistically significant differences were found between participants with (36.8 \pm 10.4 versus $33.7 \pm 11.0 ; \mathrm{t}=2.877$ [95\%CI: 0.96-5.11], $\mathrm{p}=0.004)$ and without history of abortion. 
It should be noted that among patients who reported induced abortion history, the age groups prevalence was as follows: 18 to 29 years old (23.9\%), 30 to 59 years old (32.9\%) and 60 years old or more $(27.3 \%, \mathrm{p}=0.094)$ (data not displayed in table).

\section{Substance use and history of induced abortion}

The substance user sample characteristics are displayed in Table 2. The most frequent drug of choice was cocaine (inhaled and smoked) at $69.6 \%$ and alcohol at $30.4 \%$. It was observed among the subjects with history of induced abortion the predominance of severe alcohol dependence (SADD) (32.1\%, $\chi^{2}$ $(3)=13.152, \mathrm{p}=0.004)$, drug use substantial/severe (DAST) $\left(33 \%, \chi^{2}(2)=24.81, \mathrm{p}<0.001\right)$, tobacco use $\left(32.2 \% \chi^{2}(1)=13.33, \mathrm{p}<0.001\right)$ and very low/low/moderate $(\mathrm{FTND})\left(33.5 \% \chi^{2}(1)=16.68, \mathrm{p}<0.001\right)$, with statistically significant difference. Amphetamine and injectable drug users were not identified in the sample, although this was not an exclusion criterion.

The average period of previous addiction treatment reported by subjects (mean $2.6 \pm 3.4$ versus $2.5 \pm 3.0 ; t=0.517$ [95\%CI: $0.45-0.77$ ], $\mathrm{p}=0.605$ ) did not differ significantly in the sample.

Tobacco use length in this sample was $17.1 \pm 11.2$ years. When comparing groups it was observed that participants with induced abortion history had been tobacco users for a longer period of time (mean 18.9 \pm 11.6 versus $14.9 \pm 3.3 ; t=2.260$ [95\%CI: $0.34-4.93$ ], $\mathrm{p}=0.024$ ) when compared to those without induced abortion history. The length of use of other illicit substances (mean $17.3 \pm 9.9$ versus $15.0 \pm 10.1 ; t=2.314$, [95\%CI: 0.34-4.18; $\mathrm{p}=0.021$ ) and without a history of induced abortion differ significantly in the sample.

Table 2

Data on drug of choice, severity of dependence, and history of induced abortion among drug users.

\begin{tabular}{|c|c|c|c|c|c|c|c|}
\hline & \multicolumn{6}{|c|}{ History of induced abortion } & \multirow[t]{4}{*}{ p-value } \\
\hline & \multirow{2}{*}{\multicolumn{2}{|c|}{$\begin{array}{c}\text { Total } \\
(n=616 ; 100.0 \%)\end{array}$}} & \multirow{2}{*}{\multicolumn{2}{|c|}{$\begin{array}{c}\text { Yes } \\
(n=165 ; 26.8 \%)\end{array}$}} & \multirow{2}{*}{\multicolumn{2}{|c|}{$\begin{array}{c}\text { No } \\
(n=451 ; 73.2 \%)\end{array}$}} & \\
\hline & & & & & & & \\
\hline & $\mathbf{n}$ & $\%$ & $\mathbf{n}$ & $\%$ & $\mathbf{n}$ & $\%$ & \\
\hline \multicolumn{8}{|l|}{ Drug of choice } \\
\hline Alcohol & 187 & 30.4 & 60 & 32.1 & 127 & 67.9 & 0.032 * \\
\hline Cocaine (inhaled and smoked) & 429 & 69.6 & 105 & 24.5 & 324 & 75.5 & \\
\hline \multicolumn{8}{|l|}{ SAAD } \\
\hline Mild dependence & 78 & 12.6 & 24 & 30.8 & 54 & 69.2 & 0.004 \\
\hline Moderate dependence & 121 & 19.6 & 33 & 27.3 & 88 & 72.7 & \\
\hline Severe dependence & 175 & 28.4 & 61 & 34.9 & 114 & 65.1 & \\
\hline Does not use alcohol & 242 & 24.2 & 47 & 19.4 & 195 & 80.6 & \\
\hline \multicolumn{8}{|l|}{ DAST } \\
\hline No problem/Low/Moderate & 178 & 28.9 & 23 & 12.9 & 155 & 87.1 & $<0.001$ \\
\hline substantial/Severe & 336 & 54.6 & 111 & 33.0 & 225 & 67.0 & \\
\hline No illicit drug use & 102 & 16.5 & 31 & 30.4 & 71 & 69.6 & \\
\hline \multicolumn{8}{|l|}{ Tobacco } \\
\hline Yes & 367 & 59.6 & 118 & 32.2 & 249 & 67.8 & $<0.001 *$ \\
\hline No & 249 & 40.4 & 47 & 18.9 & 202 & 81.1 & \\
\hline \multicolumn{8}{|l|}{ FTND } \\
\hline Very low/Low/Moderate & 245 & 39.8 & 82 & 33.5 & 163 & 66.5 & $<0.001$ \\
\hline high/Very high & 163 & 26.5 & 48 & 29.4 & 115 & 70.6 & \\
\hline Non-smoker & 208 & 33.7 & 35 & 16.8 & 173 & 83.2 & \\
\hline
\end{tabular}

DAST: Drug Abuse Screening Test; FTND: Fagerström Test for Nicotine Dependence; SAAD: Short Alcohol Dependence Data.

* Descriptive level of Fisher's exact test ( $p$-value $\leq 0.005$ ).

Note: descriptive level of the chi-squared test (test statistics; degrees of freedom) $N=616$. 


\section{Sexual behaviors and history of induced abortion}

Sexual behaviors and history of induced abortion in the sample are presented in Table 3. Sexual behaviors such as having an active sexual life $\left(32 \%, \chi^{2}(1)=11.725, \mathrm{p}=0.001\right)$, homosexual experience in life (41.7\%, $\left.\chi^{2}(2)=7.26, \mathrm{p}=0.026\right)$, homosexual experience in exchange for drugs $\left(37.9 \%, \chi^{2}(1)=4.63\right.$, $\mathrm{p}=0.031)$, low frequency of condom use $\left(36.3 \%, \chi^{2}(2)=23.70, \mathrm{p}=0.001\right)$, HIV testing $\left(33.2 \%, \chi^{2}(1)=\right.$ $23.85, \mathrm{p}=0.001)$, use of the morning-after pill $\left(55.9 \%, \chi^{2}(1)=15.53, \mathrm{p}=0.001\right)$ and having three or more partners $\left(32 \%, \chi^{2}(1)=4.23, \mathrm{p}=0.040\right)$ were all positively associated to induced abortion history in this sample.

\section{Table 3}

Sexual behavior and history of induced abortion among drug users.

\begin{tabular}{|c|c|c|c|c|c|c|c|}
\hline & \multicolumn{6}{|c|}{ History of induced abortion } & \multirow[t]{4}{*}{ p-value } \\
\hline & \multirow{2}{*}{\multicolumn{2}{|c|}{$\begin{array}{c}\text { Total } \\
(n=616 ; 100.0 \%)\end{array}$}} & \multirow{2}{*}{\multicolumn{2}{|c|}{$\begin{array}{c}\text { Yes } \\
(n=165 ; 26.8 \%)\end{array}$}} & \multirow{2}{*}{\multicolumn{2}{|c|}{$\begin{array}{c}\text { No } \\
(n=451 ; 73.2 \%)\end{array}$}} & \\
\hline & & & & & & & \\
\hline & $\mathbf{n}$ & $\%$ & $\mathbf{n}$ & $\%$ & $\mathbf{n}$ & $\%$ & \\
\hline \multicolumn{8}{|c|}{ Sexual activity in the past 12 months } \\
\hline Yes & 440 & 71.4 & 141 & 32.0 & 299 & 68.0 & $<0.001$ * \\
\hline No & 176 & 28.6 & 24 & 13.6 & 152 & 86.4 & \\
\hline \multicolumn{8}{|c|}{ Homosexual experience } \\
\hline Never & 482 & 78.2 & 118 & 24.5 & 364 & 75.5 & 0.026 \\
\hline At least once & 36 & 5.9 & 15 & 41.7 & 21 & 58.3 & \\
\hline More than once & 97 & 15.9 & 32 & 33.0 & 65 & 67.0 & \\
\hline \multicolumn{8}{|l|}{ Sexual orientation } \\
\hline Heterosexual & 573 & 93.0 & 156 & 94.5 & 417 & 92.5 & 0.239 * \\
\hline Homosexual & 43 & 7.0 & 9 & 5.5 & 34 & 7.5 & \\
\hline \multicolumn{8}{|c|}{$\begin{array}{l}\text { Homosexual experience in exchange for } \\
\text { drugs }\end{array}$} \\
\hline Yes & 66 & 10.7 & 25 & 37.9 & 41 & 62.1 & 0.025 * \\
\hline No & 550 & 89.3 & 140 & 25.5 & 410 & 74.5 & \\
\hline \multicolumn{8}{|l|}{ Sex with sex workers } \\
\hline Yes & 308 & 50.0 & 89 & 28.9 & 219 & 71.1 & 0.137 * \\
\hline No & 308 & 50.0 & 76 & 24.7 & 232 & 75.3 & \\
\hline \multicolumn{8}{|l|}{ Condom use } \\
\hline No use & 215 & 34.9 & 71 & 33.0 & 144 & 67.0 & $<0.001$ \\
\hline Sometimes & 135 & 21.9 & 49 & 36.3 & 86 & 63.7 & \\
\hline Always & 266 & 43.1 & 45 & 16.9 & 221 & 83.1 & \\
\hline \multicolumn{8}{|l|}{ History of STIS } \\
\hline Yes & 145 & 23.5 & 58 & 40.0 & 87 & 60.0 & 0.530 * \\
\hline No & 471 & 76.5 & 107 & 22.7 & 364 & 77.3 & \\
\hline \multicolumn{8}{|l|}{ HIV testing } \\
\hline Yes & 401 & 65.0 & 133 & 33.2 & 268 & 66.8 & $<0.001$ * \\
\hline No & 215 & 35.0 & 32 & 14.9 & 183 & 85.1 & \\
\hline \multicolumn{8}{|c|}{ Use of the morning-after pill } \\
\hline Yes & 34 & 5.5 & 19 & 55.9 & 15 & 44.1 & $<0.001$ * \\
\hline No & 582 & 94.5 & 146 & 25.1 & 436 & 74.9 & \\
\hline \multicolumn{8}{|c|}{$\begin{array}{l}\text { Number of sexual partners in the last } 12 \\
\text { months }\end{array}$} \\
\hline Up to 2 & 413 & 67.0 & 100 & 24.2 & 313 & 75.8 & 0.026 \\
\hline 3 or more & 203 & 33.0 & 65 & 32.0 & 138 & 68.0 & \\
\hline
\end{tabular}

STI: sexually transmitted infection.

* Descriptive level of Fisher's exact test.

Note: descriptive level of the chi-squared test, $N=616$. 
For average first sexual intercourse age with penetration (oral, vaginal, anal) among participants with induced abortion history (mean $14.6 \pm 2.8$ versus $14.9, \pm 3.3 ; t=-1.163$ [95\%CI: $0.24-0.94], \mathrm{p}=0.245$ ) and without induced abortion history, no significant difference was observed.

\section{Logistical regression analysis}

According to the logistic regression analyses, abortion history chance is greater in women $(\mathrm{OR}=2.9$, 95\%CI: 1.75-4.76, $\mathrm{p}=0.001)$, single $(\mathrm{OR}=1.8,95 \% \mathrm{CI}: 1.13-3.12, \mathrm{p}=0.014)$, full unemployed $(\mathrm{OR}=2.4$, 95\%CI: $1.46-3.82, \mathrm{p}=0.001)$, tobacco users (OR $=1.6,95 \% \mathrm{CI}: 1.03-2.49, \mathrm{p}=0.037)$, sexual activity in the past 12 months $(\mathrm{OR}=2.0,95 \% \mathrm{CI}: 1.17-3.69, \mathrm{p}=0.013)$, STIs history in life $(\mathrm{OR}=2.0,95 \% \mathrm{CI}$ : 1.17-3.69, $\mathrm{p}=0.001)$ HIV test (OR = 2.0, 95\%CI: 1.32-3.53, $\mathrm{p}=0.002)$, occasional or no condom use in the past 12 months $(\mathrm{OR}=1.7,95 \% \mathrm{CI}: 1.09-2.75, \mathrm{p}=0.018)$ and morning-after pill use $(\mathrm{OR}=3.2$, 95\%CI: 1.29-5.73, $\mathrm{p}=0.003$ ) (Table 4).

\section{Table 4}

Final model logistical regression analysis.

\begin{tabular}{|c|c|c|c|}
\hline & $\begin{array}{l}\text { OR unadjusted } \\
\qquad(95 \% \mathrm{Cl})\end{array}$ & $\begin{array}{l}\text { OR adjusted } \\
\qquad(95 \% \mathrm{Cl})\end{array}$ & p-value \\
\hline \multicolumn{4}{|l|}{ Gender } \\
\hline Female & $3.1(1.42-3.89)$ & $2.9(1.75-4.76)$ & 0.001 \\
\hline Male & 1.00 & 1.00 & \\
\hline \multicolumn{4}{|l|}{ Marital status } \\
\hline Unmarried & $2.6(1.04-2.37)$ & $1.8(1.13-3.12)$ & 0.014 \\
\hline Married & 1.00 & 1.00 & \\
\hline \multicolumn{4}{|l|}{ Occupational status } \\
\hline Unemployed & $2.8(1.38-2.99)$ & $2.4(1.46-3.82)$ & 0.001 \\
\hline Employed/others & 1.00 & 1.00 & \\
\hline \multicolumn{4}{|l|}{ Tobacco } \\
\hline Yes & $2.0(1.38-2.99)$ & $1.6(1.03-2.49)$ & 0.037 \\
\hline No & 1.00 & 1.00 & \\
\hline \multicolumn{4}{|l|}{ Sexual activity in the last 12 months } \\
\hline Yes & $2.9(1.85-4.80)$ & $2.0(1.17-3.69)$ & 0.013 \\
\hline No & 1.00 & 1.00 & \\
\hline \multicolumn{4}{|l|}{ Condom use } \\
\hline No use/Never use or sometimes & $2.5(1.73-3.78)$ & $1.7(1.09-2.75)$ & 0.018 \\
\hline Always & 1.00 & 1.00 & \\
\hline \multicolumn{4}{|l|}{ History of STIs } \\
\hline Yes & $2.2(1.52-3.37)$ & $2.0(1.35-3.23)$ & 0.001 \\
\hline No & 1.00 & 1.0. & \\
\hline \multicolumn{4}{|l|}{ HIV testing } \\
\hline Yes & $2.8(1.84-3.37)$ & $2.2(1.32-3.53)$ & 0.002 \\
\hline No & 1.00 & 1.00 & \\
\hline \multicolumn{4}{|l|}{ Use of the morning-after pill } \\
\hline Yes & $3.7(1.87-7.63)$ & $3.2(1.29-5.73)$ & 0.003 \\
\hline No & 1.00 & 1.00 & \\
\hline
\end{tabular}

95\%Cl: 95\% confidence interval; OR: odds ratio; STI: sexually transmitted infection. 


\section{Discussion}

In this study, 165 (26.8\%) drug users, mainly adult women, reported induced abortion history. This is one of few clinical Brazilian studies undertaken in a clinical setting to evaluate abortion prevalence in a large drug user sample. Abortion is a method used to prevent births in many developing countries 21 including in Brazil 6,35 and rates remain high around the world 13,36,37,38. The association between abortion and substance use is a public health problem of great magnitude which makes a substantial contribution to maternal morbidity and mortality 1,2,3,39.

The findings of studies that have investigated the relationship between abortion and substance use suggested several pathways by which substance use is associated to induced abortion, including engaging in risky sexual behaviors under the influence of alcohol and drugs, which increases the potential risks of an unplanned pregnancy and may lead to abortion rate increase 16,36,40,41.

Abortion scope estimates vary according to research method, sample composition, data collection strategy, sources and different conceptual definitions used by researchers 35,42 . The abortion risk evaluation is a vitally important clinical health care issue 43 . There are many obstacles preventing health care providers from taking the reproductive life history, including the history of abortion among drug users. This is a crucial strategic resource to be addressed by health care programmes, since many are the barriers which prevent pregnant patients or their partners who misuse substances from accessing and engaging in drug abuse treatment $13,14,44$.

\section{Sociodemographic data}

Variables such as gender (female), marital status (unmarried), ethnicity (Caucasian), education (illiterate), occupational status (housewife) and low income were associated to abortion in substance-related disorder patients. A previous study had reported the likely link between sociodemographic variables and abortion 44 . Abortion is influenced by several factors such as socioeconomic status, gender, educational level, income, religion, moral values and beliefs and also by alcohol and drug use 44 . However, very few studies have investigated the relationship between abortion and socioeconomic status in a substance user Brazilian sample 4,20.

From the $82.5 \%$ men of the sample, $23.8 \%$ reported abortion history. Little is known about their perspectives regarding sexual and reproductive health, or their views concerning abortion 36 . Capture some data on men's perspective regarding abortion was the reason leading to their inclusion in the analysis. Literature review reveals recurring themes concerning men's reaction to abortion. Men may suffer intense grief after abortion is undertaken by a sexual partner and they have reported feelings such as regret, helplessness, guilt, anxiety, anger, and emasculation. Each man experiences abortion in a singular way and therefore, the psychological impact of abortion on men should be taken into consideration in future studies 45 . Brazilian studies investigating abortion situations in male samples are extremely uncommon, since men are rarely included in research 6,12,36,46. Most legal abortion studies are focused on women and when abortion and contraception are discussed, attention is predominantly focused on the women's role and responsibility 46. A Brazilian literature review on abortion presented heterogeneity among women who have abortions in the country. The authors concluded that pregnancy outcome is part of their reproductive trajectories. Therefore, abortion among drug users needs to be understood in terms of its social significance.

Seventy-two (11.7\%) participants with the lowest educational level (illiterate) presented a high abortion rate (95.8\%). This finding diverges from the literature about non-drug users 36 , which suggests that an increase in educational level predicts increased support for abortion. Education has been presented as one of the most evident factors to determine people's views, with men and women of higher educational levels showing better choices in their reproductive life attitudes 47,48 . Educational level has a positive association to sympathetic attitudes regarding abortion 47,48,49. A study on educational level and income showed an inverse association to abortion risk 44.

The largest portion of this sample is at the margins of the formal labor market, a fact which aggravates psychosocial vulnerability and needs to be taken into account since lack of employment and poor professional experience result in low access to health services and information 20,29,44. Programmes and health services might not yet be prepared to recognize the specific needs required by this population 10,47. 


\section{Abortion and severity of addiction}

Abortion is known to be associated to higher rates of substance abuse 18. In this sample, all variables related to the severity of alcohol (SADD), drug (DAST) and nicotine (FTND) use were positively associated to abortion history.

Our study sample comprised cocaine users (inhaled and smoked) (69.9\%). However, alcohol was the first drug of choice and with higher severity level/SADD, presenting affirmative association to patients with abortion history. Alcohol use is widespread among more than 50\% of women of reproductive age 43 , although there is no solid evidence to suggest that alcohol is a factor which influences women seeking an abortion 50. A study which investigated the women accessing abortion services in the United States to identify whether alcohol, tobacco and other drug use, in the month prior to pregnancy awareness, contributed to their decision to terminate the pregnancy, showed that from 956 women surveyed, $2.6 \%$ identified alcohol as a reason for seeking an abortion 51 .

Due to its harmful effects, we suppose that it is possible to find higher rates of abortion history among participants who used cocaine (inhaled and smoked) 43 . In addition to being associated to induced abortion, cocaine use during the early months of pregnancy may cause an spontaneous abortion. Up to $38 \%$ of early pregnancies result in miscarriage in cocaine-abusing mothers 43,52 .

In addition, cocaine use is frequently associated to inadequate prenatal care and concomitant use of tobacco and alcohol. It has also been associated to psychosocial, behavioral and biomedical risk factors, such as poverty, malnutrition, stress, depression, physical abuse, lack of social support and STIs 24 , all of which might greatly affect the pregnancy outcome $16,43,52$.

Nicotine dependence has been investigated as a factor which affects women's health directly, causing lung cancer, heart disease and premature death 16 . Cigarette use is common among women seeking abortion 51,53,54 and this relationship has been found to be associated to unplanned pregnancy, indicating that smoking is not pregnancy-resolution related but rather pregnancy-occurrence related 16 . Studies have reported positive associations between abortion and subsequent tobacco use 23,54. A longitudinal population-based study has suggested that having an abortion may cause young women to smoke as a coping mechanism in order to deal with the stress of having had an abortion 23 .

\section{Abortion and sexual behavior}

Drug users with a history of abortion exhibit high levels of risky sexual behavior such as no condom use and history of STIs. In this study sample the sexual behavior identified was as follows: had active sexual life in the previous 12 months, had a homosexual experience (more than once), had a homosexual experience in exchange for drugs, had used condoms occasionally or never, had been tested for HIV, had used the morning-after pill and had three or more partners in the previous 12 months, this latter showing the highest prevalence and a positive association to abortion history. Substance-dependent people may engage in risky sexual behavior associated to increased potential interruption of pregnancy 21 , such as sexual intercourse without condom and homosexual experiences in exchange for drugs 24 .

Brazilian studies highlight the lack of information on contraceptives among women who have abortions, especially youth. They also show that, despite being familiar to the contraceptive methods available, Brazilian women had not used them in the period preceding the pregnancy episode investigated 6. Moreover, AIDS prevention campaigns have failed because they have promoted abstinence, fidelity and condom use. What is often neglected is that condom use requires strong partner co-operation and abstinence is an almost impossible strategy, given that adults are almost universally involved in sexual activity 55

This study included male evaluation of induced abortion history and mainly in psychoactive substances chronic users, a theme that has limited exposure in national studies. This is the first study to report the prevalence of induced abortion history among a sample of drug users in Brazil. There is insufficient national literature to compare our data, which makes it impossible to determine if sexual behavior patterns and abortion rates are similar to those of women from national estimates. 


\section{Limitations}

The results of our study must be considered in light of some potential limitations. First, the study relies on self-reported accounts regarding abortion and substance misuse. The induced abortion history was evaluated using self-reported information, without the use of standardized tools or information from other relatives. It is also important to consider that abortion is considered a crime in Brazil and people are afraid and embarrassed to report having had an abortion. Moreover, most of those in our sample were Catholic or Evangelical. We are therefore not sure that misreporting did not affect our results. It is possible that abortion was under-reported. Besides that, the participants were asked about their history of abortion in life, and it was impossible to know whether their substance use preceded their or their partners' abortions.

Second, this study was undertaken in a specialized unit providing inpatient treatment. The recruitment took place at a voluntary tertiary service, so this substance-dependent sample may not be representative of the substance-dependent community and must be treated as a convenience sample. This sample bias may limit the external validity and generalizability of these findings. It assumed that only the most serious and motivated patients receive this type of treatment. Thus, there is a selection bias as the study reports on a single drug user segment with induced abortion history and who had complications as a result of substance use where hospitalization was necessary.

There is a need for new studies to analyze the social factors involved and reasons for induced abortion in this population. It is known that reports of induced abortion differ according to gender, ethnicity/race, and social class, reflecting the assortment of implications that may be attributed to pregnancy and abortion. Such analysis would reveal the social inequalities between women and men facing the risk of an unplanned pregnancy, incorporating discussion of sexual and reproductive rights.

Third, while we agree that sexual and reproductive health issues concerning men are understudied, the fact that the sample consisted primarily of men is also a concern. This because focusing on women would be of greater interest, especially since it is likely that many abortions take place without the male partner's knowledge plus the fact that women are not represented in clinical studies of addiction and abortion. However, our women sample was not large. It is also important to note that women continue to be under-represented in exclusive treatment service for drug abuse with low access due to many reasons including the stigma.

\section{Implications for clinical practice}

Health providers should incorporate drug user health care information strategies and multiple contraceptive methods - including injectable formulations and implants that facilitate adherence and monitoring by health professionals who perform home visits or work with outreach treatment for vulnerable populations, instead of merely promoting the use of condoms. It is widely recognized that interventions continue to be based on notions of individual agency or responsibility for prevention of STIs/HIV 14,24 .

Studies connecting knowledge, attitudes and practice are necessary to embrace the complexity and multidimensionality of the environment in which the sexuality of drug users is constructed and experienced 14,24 . In this context, one of the consistent and fitting ways to ethically face the abortion problem seems to be to primarily construe the task in favour of human dignity, which may be translated into the ability to listen without judgment to women and couples in struggle 56. There is thus an important ethical dimension in this issue, namely the need to respect human life in all its breadth and demonstrations 57,58 .

\section{Implications for future studies}

Future research should examine the extent to which characteristics such as poor mental health, lack of concern for one's health and lack of responsibility affect the reproductive choices of addicted men and women. In addition, more empirical attention should be directed towards understanding the features of personality that could be associated to an increase in induced abortion demand in drug users. 


\section{Contributors}

A. Diehl and R. Laranjeira wrote the text and worked on content review. S. C. Pillon participated in the statistics and wrote the text. M. A. Santos wrote the text. All the authors revised the final version for publication.

\section{References}

1. Pazol K, Creanga AA, Burley KD, Jamieson DJ. Abortion surveillance - United States, 2011. MMWR Surveill Summ 2014; 63:1-41.

2. Pistani ML, Ceccato MB, Voluntary practice and subjective impact of abortion on women: representations, meanings and social imaginary in clandestine scenario. Vertex 2014; 25:363-9.

3. Sorhaindo AM, Juárez-Ramírez C, Díaz Olavarrieta C, Aldaz E, Mejía Piñeros MC, Garcia S. Qualitative evidence on abortion stigma from Mexico City and five states in Mexico. Women Health 2014; 54:622-40.

4. Faúndes A, Duarte GA, Osis MJ. Conscientious objection or fear of social stigma and unawareness of ethical obligations. Int J Gynaecol Obstet 2013; 123 Suppl 3:S57-9.

5. Medeiros RD, Azevedo GD, Oliveira EA, Araújo FA, Cavalcanti FJ, Araújo GL, et al. Opinion of medical and law students of Federal University of Rio Grande do Norte about abortion in Brazil. Rev Bras Ginecol Obstet 2012; 34: 16-21.

6. Menezes G, Aquino EML. Pesquisa sobre o aborto no Brasil: avanços e desafios para o campo da saúde coletiva. Cad Saúde Pública 2009; 25 Suppl 2:S193-S204.

7. Fontes ML. The stance of abortion in the Brazilian printed media ahead of the 2010 presidential elections: the exclusion of public health from the debate. Ciênc Saúde Coletiva 2012; 17:1805-12.

8. Leal OF. "Those of you who have never had an abortion, raise your hand!” Rethinking ethnographic data on the dissemination of abortion practices among low-income populations in Brazil. Ciênc Saúde Coletiva 2012; 17: 1689-97.

9. Victora CG, Aquino EM, do Carmo Leal M, Monteiro CA, Barros FC, Szwarcwald CL. Maternal and child health in Brazil: progress and challenges. Lancet 2011; 377:1863-76.

10. Koch E, Chireau M, Pliego F, Stanford J, Haddad S, Calhoun B, et al. Abortion legislation, maternal healthcare, fertility, female literacy, sanitation, violence against women and maternal deaths: a natural experiment in 32 Mexican states. BMJ Open 2015; 5:e006013.

11. Duarte GA, Osis MJD, Faúndes A, Sousa MH. Brazilian abortion law: the opinion of judges and prosecutors. Rev Saúde Pública 2010; 44:406-20.

12. Morse ML, Fonseca SC, Barbosa MD, Calil MB, Eyer FPC. Mortalidade materna no Brasil: o que mostra a produção científica nos últimos 30 anos? Cad Saúde Pública 2011; 27:623-38.

13. Abdala N, Kershaw T, Krasnoselskikh TV, Kozlov AP. Contraception use and unplanned pregnancies among injection drug-using women in St Petersburg, Russia. J Fam Plann Reprod Health Care 2011; 37:158-64. 
14. Edelman NL, Patel H, Glasper A, Bogen-Johnston L. Sexual health risks and health-seeking behaviours among substance-misusing women. J Adv Nurs 2014; 70:2861-70.

15. Gutierres SE, Barr A. The relationship between attitudes toward pregnancy and contraception use among drug users. J Subst Abuse Treat 2003; 24:19-29.

16. Martino SC, Collins RL, Ellickson PL, Klein DJ. Exploring the link between substance abuse and abortion: the roles of unconventionality and unplanned pregnancy. Perspect Sex Reprod Health 2006; 38:66-75.

17. Paltrow LM. The war on drugs and the war on abortion: some initial thoughts on the connections, intersections and effects. Reprod Health Matters 2002; 10:162-70.

18. Roberts SC, Rocca CH, Foster D. Receiving versus being denied an abortion and subsequent drug use. Drug Alcohol Depend 2014; 134:63-70.

19. Barros FC, Matijasevich A, Requejo JH, Giugliani E, Maranhão AG, Monteiro CA, et al. Recent trends in maternal, newborn, and child health in Brazil: progress toward Millennium Development Goals 4 and 5. Am J Public Health 2010; 100:1877-89.

20. Fusco CL, Silva RS, Andreoni S. Unsafe abortion: social determinants and health inequities in a vulnerable population in São Paulo, Brazil. Cad Saúde Pública 2012; 28:709-19.

21. Abdala N, Zhan W, Shaboltas AV, Skochilov RV, Kozlov AP, Krasnoselskikh TV. Correlates of abortions and condom use among high-risk women attending an STD clinic in St. Petersburg, Russia. Reprod Health 2011; 8:28.

22. Le HH, Connolly MP, Bahamondes L, Cecatti JG, Yu J, Hu HX. The burden of unintended pregnancies in Brazil: a social and public health system cost analysis. Int J Womens Health 2014; 6:663-70.

23. Pedersen W. Childbirth, abortion and subsequent substance use in young women: a population-based longitudinal study. Addiction 2007; 102:1971-8.

24. Diehl A, Leite Vieira D, Rassool GH, Cristina Pillon S. Sexual risk behaviors in non-injecting substance-dependent Brazilian patients. Adicciones 2014; 26:208-20.

25. Dias AC, Araújo MR, Dunn J, Sesso RC, de Castro V, Laranjeira R. Mortality rate among crack/cocaine-dependent patients: a 12-year prospective cohort study conducted in Brazil. J Subst Abuse Treat 2011; 41:273-8.

26. Ward H, Pallecaros A, Green A, Day S. Health issues associated with increasing use of "crack" cocaine among female sex workers in London. Sex Transm Infect 2000; 76:292-3.

27. Cortez FC, Boer DP, Baltieri DA. Psychosocial pathways to inconsistent condom use among male sex workers: personality, drug misuse and criminality. Sex Health 2011; 8:390-8.
28. Nunes CL, Andrade T, Galvão-Castro B, Bastos FI, Reingold A. Assessing risk behaviors and prevalence of sexually transmitted and blood-borne infections among female crack cocaine users in Salvador-Bahia, Brazil. Braz J Infect Dis 2007; 11:561-6.

29. Wall M, Schmidt E, Sarang A, Atun R, Renton A. Sex, drugs and economic behaviour in Russia: a study of socio-economic characteristics of high-risk populations. Int J Drug Policy 2011; 22:133-9.

30. American Psychiatric Association. DSM-IVTR. Manual diagnóstico e estatístico de transtornos mentais. Porto Alegre: Editora Artmed; 2002.

31. Clark BC, Perkins A, McCullumsmith CB, Islam AM, Sung J, Cropsey KL. What does self-identified drug of choice tell us about individuals under community corrections supervision? J Addict Med 2012; 6:57-67.

32. Yudko E, Lozhkina O, Fouts A. A comprehensive review of the psychometric properties of the Drug Abuse Screening Test. J Subst Abuse Treat 2007; 32:189-98.

33. Rosa-Oliveira LQ, Presti PF, Antunes IRA, Carbonari GC, Imada AN, Maeda MY, et al. Reliability and dimensionality of the Short Alcohol Dependence Data (SADD) questionnaire in a clinical sample of hospitalized patients: using the SADD in a general hospital setting. Rev Bras Psiquiatr 2011; 33:68-71.

34. Meneses-Gaya CI, Zuardi AW, Loureiro SR, Crippa JA. Psychometric properties of the Fagerstrom Test for Nicotine Dependence, J Bras Pneumol 2009; 35:73-82.

35. Diniz D, Medeiros M. Aborto no Brasil: uma pesquisa domiciliar com técnica de urna. Ciênc Saúde Coletiva 2010; 15:959-66.

36. Chikovore J. Gender power dynamics in sexual and reproductive health. A qualitative study in Chiredzi District, Zimbabwe, 2004. http://www.diva-portal.org/smash/get/diva2: 142634/FULLTEXT01.PDF (accessed on 14/ $\mathrm{Jul} / 2015$ ).

37. Moore AM, Jagwe-Wadda G, Bankole A. Mens' attitudes about abortion in Uganda. J Biosoc Sci 2011; 43:31-45.

38. Pallikadavath S, Stones RW. Maternal and social factors associated with abortion in India: a population-based study. Int Fam Plan Perspect 2006; 32:120-5.

39. Chaves TV, Sanchez ZM, Ribeiro LA, Nappo SA. Fissura por crack: comportamento e estratégias de controle de usuários e ex-usuários. Rev Saúde Pública 2011; 45:1168-75.

40. Jones RK, Kavanaugh ML. Changes in abortion rates between 2000 and 2008 and lifetime incidence of abortion. Obstet Gynecol 2011; 117:1358-66.

41. Mensch BS, Kandel DB. Drug use as a risk factor for premarital teen pregnancy and abortion in a national sample of young white women. Demography 1992; 29:409-29. 
42. Lara D, Strickler J, Olavarrieta C, Ellertson C. Measuring induced abortion in Mexico: a comparison of four methodologies. Sociological Methods and Research 2004; 32:529-58.

43. Keegan J, Parva M, Finnegan M, Gerson A, Belden M. Addiction in pregnancy. J Addict Dis 2010; 29:175-91.

44. Norsker FN, Espenhaim L, Rogvi S, Morgen CS, Andersen PK, Andersen A-MN. Socioeconomic position and the risk of spontaneous abortion: a study within the Danish National Birth Cohort. BMJ Open 2012; 2:e001077.

45. Coleman PK, Rue VM, Spence M, Coyle CT. Abortion and the sexual lives of men and women: is casual sexual behavior more appealing and more common after abortion? Int J Clin Health Psychol 2008; 8:77-91.

46. Kero A, Lalos A, Högberg U, Jacobsson L. The male partner involved in legal abortion. Hum Reprod 1999; 14:2669-75.

47. Rinderknecht L. Supporting attitudes on abortion with the influence of education and gender. http://www.people.oregonstate. edu/ hammerr/soc316/Education_Gender_ and_Abortion.pdf (accessed on 17/Jul/2015).

48. Walzer $\mathrm{S}$. The roles of gender in determining abortion attitudes. Soc Sci Q 1994; 75:687-93.

49. Marsiglio W. Contemporary scholarship on fatherhood culture, identity, and conduct. J Fam Issues 1993; 14:484-509.
50. Kirkman M, Rowe H, Hardiman A, Mallett S, Rosenthal D. Reasons women give for abortion: a review of the literature. Arch Womens Ment Health 2009; 12:365-78.

51. Roberts SC, Avalos LA, Sinkford D, Foster DG. Alcohol, tobacco and drug use as reasons for abortion. Alcohol Alcohol 2012; 47:640-8.

52. Schempf AH, Strobino DM. Illicit drug use and adverse birth outcomes: is it drugs or context? J Urban Health 2008; 85:858-73.

53. Coleman PK, Maxey CD, Spence M, Nixon CL. Predictors and correlates of abortion in the fragile families and well-being study: paternal behavior, substance use, and partner violence. Int J Ment Health Addict 2009; 7:405-22.

54. Roberts SC, Foster DG. Receiving versus being denied an abortion and subsequent tobacco use. Matern Child Health J 2014; 19:438-46.

55. Parker R, Ehrhardt AA. Through an ethnographic lens: ethnographic methods, comparative analysis, and HIV/AIDS research. AIDS Behav 2001; 5:105-14.

56. Junges RJ. Bioética: perspectivas e desafios. São Leopoldo: Editora Unisinos; 1999.

57. Gracia D. Ética de los confines de la vida. Ética y vida, estúdios de bioética. v. 3. Bogotá: Editorial El Bunho; 1998.

58. Steffen L. Abortion: a reader. Cleveland: The Pilgrim Library of Ethics; 1996. 


\section{Resumo}

O aborto é uma questão altamente sensivel e com relevância para a saúde pública. Entretanto, poucos estudos clínicos ou populacionais já examinaram o aborto provocado em usuárias de drogas. O estudo tem como objetivo avaliar a prevalência de aborto provocado e condições sexuais em uma amostra de usuárias hospitalizadas. Foi realizado um estudo transversal em uma unidade hospitalar para tratamento de dependência química em São Paulo, Brasil, com uma amostra de 616 pacientes entre 18 e 75 anos de idade. Foram avaliados dados sóciodemográficos, comportamento sexual e gravidade da dependência química e a associação com o aborto provocado. Entre as próprias usuárias e seus parceiros masculinos, 27\% relataram

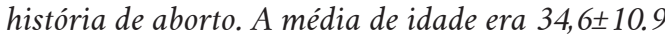
anos, 34,9\% tinham diagnóstico de dependência alcoólica grave, 33\% tinham diagnóstico de níveis graves de outras dependências química, 69,6\% usavam cocaina (inalada elou fumada) e álcool era a droga de escolha para 30,4\% da amostra. Quando comparadas aos parceiros masculinos, as mulheres relatavam chances mais elevadas nos seguintes itens: história de aborto $(O R=2,9$; IC95\%: 1,75-4,76), falta de uso de preservativo $(O R=1,7$; IC95\%: 1,09-2,75), história de DSTs (OR = 2,0; IC95\%: 1,35-3,23) e uso da pílula do dia seguinte $(O R=3,2$; IC95\%: 1,29-5,73). Os pacientes com dependência de álcool e outras drogas apresentam comportamentos de alto risco para uso nulo ou esporádico de preservativos, contribuindo para a gravidez não planejada e o aborto provocado, fazendo com que essa população vulnerável seja um grupo que merece atenção especial nos programas de prevenção em saúde sexual e nos esforços de promoção da saúde para a redução do aborto provocado.

Aborto; Saúde Sexual e Reprodutiva; Usuários de Drogas; Transtornos Relacionados ao Uso de Substâncias; Políticas Públicas

\section{Resumen}

El aborto es una cuestión altamente sensible y relevante para la salud pública. Pese a ello, pocos estudios clínicos o poblacionales han analizado el aborto provocado en consumidoras de drogas. El estudio tiene como objetivo evaluar la prevalencia de aborto provocado y las condiciones sexuales en una muestra de drogodependientes hospitalizadas. Se realizó un estudio trasversal en una unidad hospitalaria para el tratamiento de dependencia a drogas en Sao Paulo, Brasil, con una muestra de 616 pacientes entre 18 y 75 años de edad. Se evaluaron datos sociodemográficos, comportamiento sexual y gravedad de la drogodependencia y su asociación con el aborto provocado. Entre las propias drogodependientes y sus parejas masculinas, un $27 \%$ informaron de un historial de aborto.

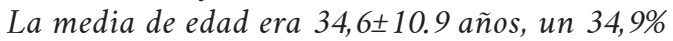
tenían un diagnóstico de dependencia alcohólica grave, un 33\% tenían un diagnóstico de niveles graves de otras dependencias a drogas, un 69,6\% consumian cocaina (inhalada y/o fumada) y el alcohol era la droga de elección para un 30,4\% de la muestra. Cuando se compara con las parejas masculinas, las mujeres presentaban oportunidades más elevadas en los siguientes items: historial de aborto $(O R=2,9$; IC95\%: 1,75-4,76), falta de uso de preservativo $(O R=1,7$; IC95\%: 1,09-2,75), historial de DSTs (OR = 2,0; IC95\%: 1,35-3,23) y uso de la píldora del día siguiente $(O R=3,2$; IC95\%: 1,29-5,73). Los pacientes con dependencia del alcohol y otras drogas presentan comportamientos de alto riesgo, asociados a un uso nulo o esporádico de preservativos, contribuyendo al embarazo no planeado y al aborto provocado, ocasionando que esa población vulnerable sea un grupo que merece atención especial en los programas de prevención en salud sexual y en los esfuerzos de promoción de la salud para la reducción del aborto provocado.

Aborto; Salud Sexual y Reproductiva; Consumidores de Drogas; Trastornos Relacionados con Sustancias; Políticas Públicas
Submitted on 16/Aug/2016

Final version resubmitted on 13/Dec/2016

Approved on 06/Feb/2017 